\title{
Acute Toxicity Assessment and Behavioral Responses Induced by Kandhamal haladi in Adult Zebrafish (Danio rerio)
}

\author{
Laxminandan Satpathy ${ }^{1}$, Siba Prasad Parida ${ }^{2, *}$ \\ 1 Department of Zoology, School of Applied Sciences, Centurion University of Technology and Management, \\ Bhubaneswar, Odisha, 752050 India; laxminandansatpathy@gmail.com; \\ 2 Department of Zoology, School of Applied Sciences, Centurion University of Technology and Management, \\ Bhubaneswar, Odisha, 752050 India; paridasp@gmail.com; \\ * Correspondence: paridasp@gmail.com;
}

Scopus Author ID 57197747626

Received: 20.05.2020; Revised: 13.06.2020; Accepted: 14.06.2020; Published: 16.06.2020

\begin{abstract}
Turmeric has been used traditionally for its antimicrobial activity. Turmeric is used as a spice, food preservative, and coloring material in India. It has been used in Ayurveda for various diseases. So we decided to evaluate the toxicity effect of Kandhamal haladi, commonly use in the food industry, cosmetics, and pharmacology. The adult zebrafish (Danio rerio) model was used to evaluate the median lethal concentration $\left(\mathrm{LC}_{50}\right)$. In the present study, acute toxic effects and behavioral alterations induced by exposure of the freshwater fish Danio rerio (zebrafish) to Kandhamal haladi was reported. Seven healthy specimens of the average size (3-4 cm in length and $1.0 \pm 0.78 \mathrm{~g}$ in weight) in each group were exposed to different concentrations of Kandhamal haladi for 24 h, 48 h, 72 h, and 96 $\mathrm{h}$ along with naïve and control group in a static system. After $96 \mathrm{~h}$ exposure at a water temperature of $28.5^{\circ} \mathrm{C}$, their abnormal swimming behavioral patterns and abnormal ventilatory (respiratory) function, including hyperactivity, hypoactivity, and gulping, were observed. Alterations in behavioral patterns were well noticeable during the period of the experiment. The $96 \mathrm{~h} \mathrm{LC}_{50}$ value of Kandhamal haladi to Danio rerio was found to be $173.516 \mu \mathrm{M}$ with lower and upper confidential limits (95\%) as 152.146 $\mu \mathrm{M}$ and $200.072 \mu \mathrm{M}$ respectively by using IBM SPSS statistics 25 software and $173.780 \mu \mathrm{M}$ using Microsoft Office Excel 2007 based on Finney's probit analysis statistical method. Mortality and behavioral changes were increased with increasing concentration of the compound within 24 to 96 hours. In addition to dose and dose-time dependent increase in the mortality rate, anxiety signs in the form of behavioral changes were observed in response to different test concentrations. Further researches are recommended to study the processes by which this chemical affects physiology and histology of fish and their accumulation in fish tissues. Our findings suggest that Kandhamal haladi can be used to fight against different fish diseases because of its low toxic effect on fishes, and supplementation of haladi could be recommended in aquaculture through a feed to prevent disease impact.
\end{abstract}

Keywords: acute toxicity; behavioral changes; geographical indication (GI) tag; Kandhamal haladi $(\mathrm{KH})$; median lethal concentration $\left(\mathrm{LC}_{50}\right)$; Finney's probit analysis; adult zebra fish.

\footnotetext{
(C) 2020 by the authors. This article is an open-access article distributed under the terms and conditions of the Creative Commons Attribution (CC BY) license (https://creativecommons.org/licenses/by/4.0/).
}

\section{Introduction}

Turmeric derives its name from the Latin word "terra merita," meaning meritorious earth, implying to the color of ground turmeric, which resembling a golden pigment. It was in 1753 that the genus Curcuma was established by Linnaeus in his Species Plantarum [1]. This 
was based on a plant observed by Hermann in what was then known as Ceylon (now Sri Lanka). The generic epithet is derived from the Arabic word karkum, meaning yellow, referring to the yellow color of the rhizome, and Curcuma is the Latinized version [2-3]. Curcuma was described early (1678-1693) by Van Rheede in Hortus Indicus Malabaricus [4]. He recorded two species of Curcuma under the local names "Kua" and "Manjella Kua," which were later identified as Curcuma zedoaria Rosc. and Curcuma longa L., respectively [5]. "Manjella Kua" was selected as lectotype of Curcuma longa L. by Burtt (1977) [5]. He further reinstated the name of Curcuma longa L. and Curcuma domestica Val. as its synonym belongs to the family Zingiberaceae. The genus Curcuma consists of about 110 species distributed chiefly in South and Southeast Asia. Hooker (1879) confirmed 27 species of Curcuma in British India (The Flora of British India) [6]. Turmeric (Curcuma longa L.) is a rhizomatous herbaceous perennial plant of the ginger family and used in India for thousands of years as a part of food preparation and many major Ayurvedic and Siddha drugs [7-8]. It was first used as a dye and later for its medicinal properties and is reported that its extracts have antifungal and antibacterial properties [9]. Turmeric is under evaluation for its potential effect on Alzheimer's disease and diabetes [10-11]. Turmeric or Haladi is widely used in Ayurveda and Siddha formulations for treating various diseases like biliary disorders, anorexia, cough, diabetes, wounds, hepatic disorders, rheumatism, and sinusitis [12]. Ichthyophthirius multifiliis is a ciliated parasite that elicits great economic losses in aquaculture [13]. Curcumin has the potential to be a safe and effective therapeutics for controlling ichthyophthiriasis in aquaculture [13]. Turmeric supplementation in the food of Labeo rohita (Linn.) reduced bacterial pathogenicity of Aeromonas veronii [14]. Mycobacteriosis is a common disease of laboratory zebrafish as well as wild and captive fishes worldwide [15-16]. Mycobacteriosis is a significant and commonly identified disease in zebrafish research facility [17]. Mycobacterium species have long been recognized as a significant source of morbidity and mortality in finfish aquaculture, as well as in wild finfishes. Mycobacteria infecting fishes also include zoonotic pathogens that can cause protracted illness, especially in immune-compromised individuals [18]. Mycobacteriosis also affects birds throughout the world, and the species pathogenic to birds are considered ubiquitous environmental saprophytes [19]. Turmeric has antimicrobial and anti-protozoal activity. Mycobacteriosis may be prevented and cured by turmeric. It contains many phytochemicals like curcumin, bis-methoxy-curcumin, d-methoxy-curcumin, curcuminol, curcumol, eugenol, terta-hydro-curcumin, tri-ethyl-curcumin, turmerine, turmerols, volatile oils (turmerone, atlantone, and zingiberene), sugars, proteins, and resins [20-21]. The pharmacological activity of turmeric has been attributed mainly to curcuminoids [22]. In our present study, acute toxicity bioassay and behavioral studies were carried out in a static system to determine the LC50 values for 96 hours.

\subsection{Geographical indication status in India.}

The protection of geographical indications (GIs) has, over the years, emerged as one of the most contentious intellectual property rights issues in the realm of the World Trade Organization (WTO) [23]. In 2019 two products from the state of Odisha got GI tag out of which one is Kandhamal haladi $(\mathrm{KH})$ by intellectual property India. Kandhamal haladi $(\mathrm{KH})$ got geographical indication number- 610 been placed under class- 30 . 


\subsection{Kandhamal haladi $(K H)$.}

In India, turmeric is known as "haladi". Kandhamal haladi or Kandhamal turmeric is a variety of turmeric indigenous to southern Odisha. Kandhamal is a district in the state of Odisha and is famed for its turmeric. The agricultural product stands out for its healing properties. The local variety of turmeric grown from ancient times is having $2-3 \%$ curcumin (Figure 1), 12$15 \%$ of oleoresin [Demethoxycurcumin (Figure 2), and Bisdemethoxycurcumin (Figure 3)], and $5.3 \%$ of volatile oil [24]. Kandhamal haladi has more oleoresin and volatile oil contents compared to other turmeric varieties [24]. It gives a strong aroma and has a high medicinal value.

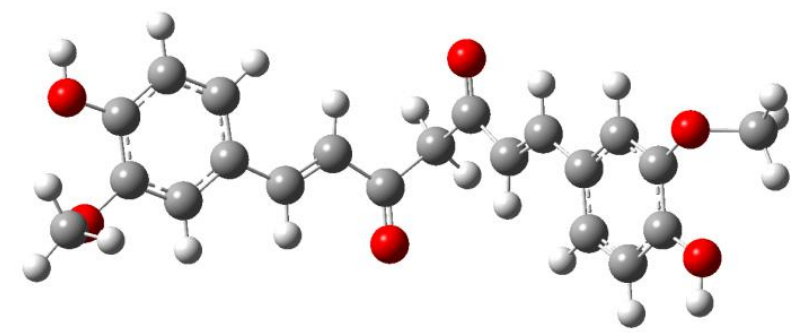

Figure 1. Structure of curcumin using GaussView 4.1.2.

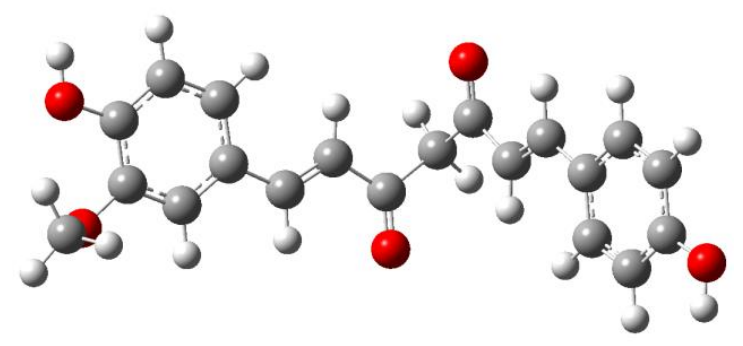

Figure 2. Structure of Demethoxycurcumin using GaussView 4.1.2.

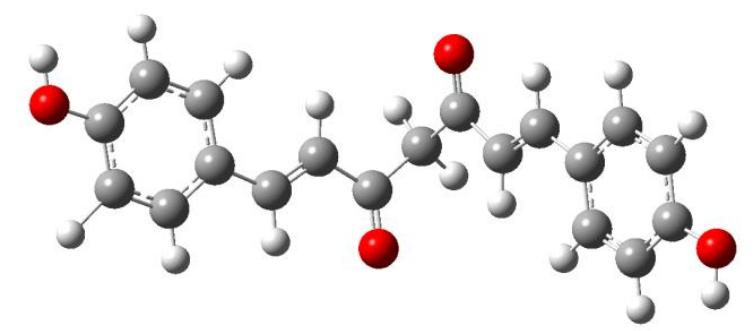

Figure 3. Structure of Bisdemethoxycurcumin using GaussView 4.1.2.

\subsection{Zebrafish (Danio rerio) as a toxicity model.}

The zebrafish (Danio rerio) is a small tropical fish, member of the minnow family Cyprinidae of the order Cypriniformes. Hamilton (1822) described Cyprinus rerio from Gangetic provinces in the book "An account of the fishes found in the river Ganges and its branches", together with the other ten species [25]. The name Danio is derived from the Hindi word Dhan which means paddy [26]. It is a popular aquarium fish, its trade name zebra danio in India (and thus often called a "tropical fish" although both tropical and subtropical). Globally zebrafish known as "leopard danio" and vernacular name for zebrafish in Odia language is "poncho geraldi" [27]. Danio rerio is distributed throughout South and Southeast Asia. The natural occurrence of the species is predominantly related to the Ganges and Brahmaputra river basin localized in north-eastern India, Bangladesh, and Nepal [28-29]. In the early 1970's, scientists of the University of Oregon determined the zebrafish as a vertebrate model for 
development and genetics. Dr George Streisinger (1927-1984) is considered the founding father of zebrafish research [30]. Together with Dr Charles Kimmel and other researchers of the University of Oregon's Institute of Molecular Biology, he published several studies on zebrafish development and genetics [31]. Nowadays, hundreds of research centers worldwide use zebrafish in fundamental and applied research. In the last decade, zebrafish have become an important model organism in the field of biomedical, eco-toxicological, and genetics. The intricate features of zebrafish render this fish a novel vertebrate model among the organisms. Consequently, the zebrafish has become a popular model organism also for clarification of the roles of specific genes and signaling pathways during the development [32-33]. An increasing interest emerged in the field of toxicology and ecotoxicology as a non-mammalian vertebrate organism in risk assessment and regulation. Zebrafish share physiological, morphological, and histological similarities with mammals and have been recognized as valuable models for evaluating drug candidates for toxicity and safety liabilities [34]. The zebrafish has its advantages compared to the traditional in vivo model like the mouse in that multiple organs can be observed; pharmacodynamic, pharmacokinetic, and metabolite activity can be evaluated; low cost; short life cycle; less amounts of a test compound; and high output [35]. Zebrafish model system has been successfully used in studying developmental toxicity, teratogenicity, cardiovascular toxicity, liver toxicity, behavioral toxicity, kidney toxicity, and a series of evaluation assays [36]. But what boosted the scientific community to recognize zebrafish as leading vertebrate organism in the above-mentioned field, has been the complete sequencing of its genome [37]. The zebrafish (Danio rerio) is an important vertebrate model organism in scientific research. As a model biological system, the zebrafish possesses numerous advantages for researchers. However, detailed studies on the pharmacological activity and potency of Kandhamal haladi in its unrefined natural state are scanty. This study gives the gross effects of natural state Kandhamal haladi on adult zebrafish.

\subsection{Median lethal concentration $\left(L C_{50}\right)$.}

Toxicology can be defined as that branch of science that deals with poisons and a poison can be defined as any substance that causes a harmful effect when administered, either by accident or design, to a living organism [38]. Median lethal concentration (LC50) is the concentration of a test chemical that is estimated to be lethal to $50 \%$ of the test organisms within the test duration [39]. In environmental studies, it can also mean the concentration of a chemical in water. According to the Organisation for Economic Cooperation and Development [39] guidelines for the testing of chemicals, a traditional experiment involves groups of animals exposed to a specific concentration (ccohs). However, in this case, both exposure time and concentrations are important. Research studies described the highest doses at which no toxic effects were observed, and at lowest doses, toxic or adverse effects were observed. The terms refer to the actual doses used in experimental animal studies are NOEL (no observed effect level) and LOEL (lowest observed effect level). For many chemicals and effects, there will be a dose below which no effect or response is observed. This is called the threshold dose. This concept is of significance because it implies that a no observed effect level (NOEL) can be determined and that this value can be used to determine the safe intake for food additives such as turmeric and contaminants such as pesticides. Alternatives that are occasionally used in place of $\mathrm{LC}_{50}$ are the $\mathrm{LC}_{25}$ and $\mathrm{LC}_{75}$, which refer to the lethal concentration that kills $25 \%$ and $75 \%$ of test subjects, respectively. There are some criteria for aquatic environment toxicity by GHS (Globally Harmonized System of Classification and Labelling of Chemicals) [40] (Table 
1). Toxicants enter into the body through ingestion, skin, and inhalation. It is absorbed into the bloodstream and distribution throughout the body tissues and organs and affects body metabolism [38] (Fig 4).

Table 1. GHS (Globally Harmonized System of Classification and Labelling of Chemicals) criteria for aquatic environment toxicity [40].

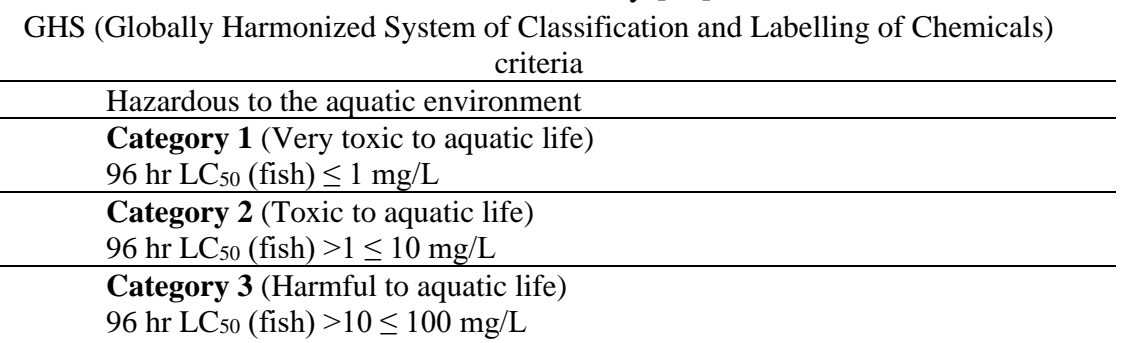

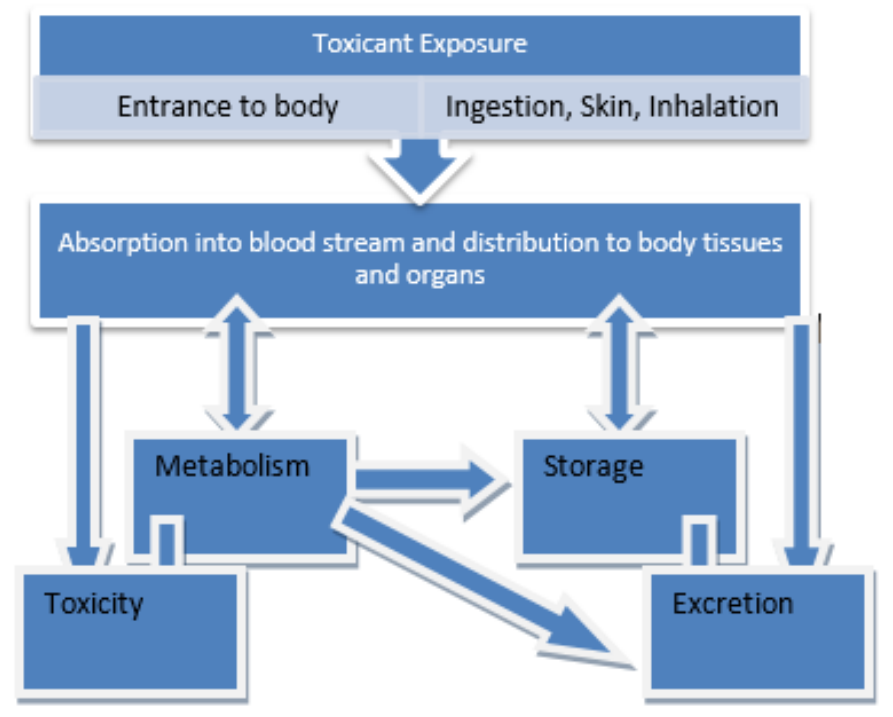

Figure 4. Fate and effect of toxicants on the living system [38].

\section{Materials and Methods}

\subsection{Chemicals and reagents.}

The imperative chemicals and standard reagents used in the experiments were purchased from Sigma-Aldrich unless otherwise mentioned.

\subsection{Experimental animals.}

Adult zebrafish (short-fin, 6-8 month-old, 3-4 cm in length, 50:50 male: female ratio and weigh about $1.0 \pm 0.78 \mathrm{~g}$ ) were collected from ornamental fish hatchery of the Central Institute of Freshwater Aquaculture (CIFA), Odisha, India and were maintained in a 50-L aquarium at $28.5^{\circ} \mathrm{C}$. Tanks were filled with filtered water, and the $\mathrm{pH}$ of the system water was checked daily and was maintained between $6.8-7.5$. When necessary, sodium bicarbonate was used to increase the $\mathrm{pH}$. The salinity and hardness of water were maintained between 0 to 0.1 ppt and $100 \mathrm{mg} / \mathrm{L} \mathrm{CaCO}_{3}$, respectively. They were left for acclimatization for 9 days (48 hours settling-in +7 days acclimatization) and feed twice per diem with packed fish food collected from a pet store, and dead fish were immediately removed to avoid possible putrefaction with the deterioration of water quality. Illumination was provided by ceiling-mounted light tubes on a 14:10 h (day: night) cycle, consistent with the zebrafish standard of care. The zebrafish were divided into three experimental groups such as naive (without any supplementation), control 
(supplemented with the vehicle, dimethyl sulfoxide), and Kandhamal haladi (supplemented with Kandhamal turmeric). Seven zebrafish per group were taken in triplicates and maintained with different doses $(20 \mu \mathrm{M}$ to $300 \mu \mathrm{M})$ of Kandhamal haladi or Kandhamal turmeric in 2-L capacity rectangular aerated glass containers. No food was provided to the fishes during the assessment. The fishes were exposed to the test chemical, i.e., Kandhamal turmeric, for a period of 96 hours, under static condition. Fishes were considered dead when there was no visible movement (e.g., no opercular motion), and touching the caudal peduncle produced no reaction. Mortalities and visible abnormalities related to appearance and behavior were recorded. The concentrations to kill $50 \%$ of the fish ( $\left.\mathrm{LC}_{50}\right)$ are determined $[41-43,39]$. The acute toxic effect of zebrafish within $96 \mathrm{~h}$ was determined as $\mathrm{LC}_{50}$ and then subjected to probit analyses by Finney's method using Microsoft Office Excel 2007 and using the IBM SPSS Statistics version 25 software to estimate $\mathrm{LC}_{1}$ to $\mathrm{LC}_{99}$ values (Figure 5). Results with $\mathrm{p}<0.05$ were considered to be statistically significant. The $\mathrm{LC}_{50}$ value is obtained by using the regression equation arithmetically and also by graphical interpolation by taking logarithms of the Kandhamal haladi concentration versus probit value of percentage mortality.

\subsection{Dose standardization of Kandhamal haladi $(K H)$.}

A waterborne acute toxicity test for turmeric was carried out to determine the doseresponse curve [39]. Kandhamal haladi $(\mathrm{KH})$ was dissolved in $0.1 \%$ dimethyl sulfoxide (DMSO) [44]. Then the Kandhamal turmeric was supplemented at different concentrations of $20 \mu \mathrm{M}, 40 \mu \mathrm{M}, 60 \mu \mathrm{M}, 80 \mu \mathrm{M}, 100 \mu \mathrm{M}, 120 \mu \mathrm{M}, 140 \mu \mathrm{M}, 160 \mu \mathrm{M}, 180 \mu \mathrm{M}, 200 \mu \mathrm{M}, 220$ $\mu \mathrm{M}, 240 \mu \mathrm{M}, 260 \mu \mathrm{M}, 280 \mu \mathrm{M}$, and $300 \mu \mathrm{M}$ for waterborne administration for a period of 96 hours.

\section{Results and Discussion}

The mortality of the adult zebrafish for Kandhamal haladi doses $20 \mu \mathrm{M}, 40 \mu \mathrm{M}, 60 \mu \mathrm{M}$, $80 \mu \mathrm{M}, 100 \mu \mathrm{M}, 120 \mu \mathrm{M}, 140 \mu \mathrm{M}, 160 \mu \mathrm{M}, 180 \mu \mathrm{M}, 200 \mu \mathrm{M}, 220 \mu \mathrm{M}, 240 \mu \mathrm{M}, 260 \mu \mathrm{M}, 280$ $\mu \mathrm{M}$, and $300 \mu \mathrm{M}$ were examined for a duration of $96 \mathrm{~h}$ (Table 4). No naïve fish died during the acclimatization before exposure, and no control fish died during acute toxicity tests. Adult zebrafish exposed during the period $24 \mathrm{~h}$ to $96 \mathrm{~h}$ had significantly increased in mortality with increasing concentration. There were significant differences in the number of dead adult zebrafish between the duration of $24 \mathrm{~h}$ to $96 \mathrm{~h}$ in each group. There was a $100 \%$ mortality above $400 \mu \mathrm{M}$ concentration within the $96 \mathrm{~h}$ dose for all fishes. Median lethal concentrations of $1 \%, 10 \%, 20 \%, 30 \%, 40 \%, 50 \%, 60 \%, 70 \%, 80 \%, 90 \%$ and $99 \%$ test are presented in Table

5. Because mortality data are collected for each exposure concentration in a toxicity test for durations of 96 hours, data can be plotted in the straight line of best fit is then drawn through the points (Figure 5 and Figure 6). Behavioral change was for a general adaptation of organisms towards environmental stress. Behavioral changes presented in Supplementary Table 2 (Supplementary data) records the behavioral responses, including hyperactivity (Figure 7), hypoactivity (Figure 8), and gulping (Figure 9) with a standard error of the mean (SEM). Within the naïve and control group, no significant changes in behavioral responses were detected. In the case of Kandhamal haladi exposure, behavior changed with exposure time and concentration. Higher concentrations resulted in a greater degree of the behavioral responses, which may be due to the toxic effect exerted by the Kandhamal haladi. 


\subsection{Statistical analysis.}

Significant differences $(P<0.05)$ were observed in the LC50 mean values for the zebra fish to each concentration of Kandhamal haladi (Table 4). The logarithmic value of the concentration was obtained by interpolation from the linear correlation between probits and $\log$ (c). The $\mathrm{LC}_{50}$ values in $96 \mathrm{~h}$ time intervals were determined by probit analysis (Supplementary Data, Supplementary Table 3), with a confident limit of $5 \%$ level [45]. The $\mathrm{LC}_{50}$ value (with 95\% confidence limits), the correlation between mortality against concentrations were obtained. Different concentrations of Kandhamal haladi showed a different percentage of mortality (Figure 5 and Figure 6). It was detected only at the concentration of $20 \mu \mathrm{M}$ no mortality was observed at $96 \mathrm{~h}$, whereas at $400 \mu \mathrm{M}$ showed $100 \%$ mortality of the animal. Computation of median lethal concentration by probit analysis using IBM SPSS Statistics 25 and Microsoft Office Excel 2007 showed LC50 value at $173.516 \mu \mathrm{M}$ and $173.780 \mu \mathrm{M}$, respectively. The LC $\mathrm{C}_{50}$ values were highly significant, $\mathrm{p}<0.05$ (Table 6 and Table 7). The values are also plotted as a graph, and the results of correlation analysis using Microsoft Office Excel 2007 showed that \% mortality (Y-variable) against concentrations of Kandhamal haladi (X-variable) was highly positive correlation $r=+0.986$ (Figure 6). Probit transformed response graph plotted by using IBM SPSS Statistic 25 also showed a highly positive correlation $r=+0.926$ (Figure 5). It was observed that at the concentration above 400 $\mu \mathrm{M}$ showed $100 \%$ mortality. Tables 6 and 7 depicted the parameter estimates of probit analysis and chi-square test for the acute toxicity of Kandhamal haladi to Danio rerio. The behavior of the animal showed a drastic alteration in Kandhamal haladi-treated zebrafish when compared to control group and naïve group, where at the beginning of the treatment, all the fishes showed spontaneous swimming activity, and it gradually decreased to become lethargic (Figure 7 and Figure 8). Irregular, erratic, abnormal swimming movements, reactive to stimulus, schooling behavior, and change in body pigmentation became more apparent with an increase in the duration of exposure at all test concentrations. Too much behavioral changes (cough, mucus secretion, irregular ventilation, and yawn) at higher concentration might be due to demonstration of the disturbances in the physiological mechanism which is supposed to initiate, maintain and terminate the behavior [46]. It may reduce the supply of oxygen and causing immediate fish death. With increasing exposure, their opercular movements became least and died with mouth opened. It was concluded that Kandhamal haladi is low toxic and does not have a significant effect on the behavior in low doses, which has less toxic to the health of adult zebrafish, whereas curcumin had moderate acute toxicity in embryo zebrafish assay [35].

Table 2. Clinical signs and symptoms observed in adult zebrafish [39].

\begin{tabular}{l|l|l} 
Clinical sign & Definition & Synonyms \\
\hline LOSS OF EQUILIBRIUM (sub-categories below) & Keeling lost righting reflex \\
$\begin{array}{l}\text { Abnormal horizontal } \\
\text { orientation }\end{array}$ & $\begin{array}{l}\text { Loss of balance displaying as abnormal } \\
\text { horizontal } \\
\text { orientation/posture in the water column }\end{array}$ & \\
\hline $\begin{array}{l}\text { Abnormal vertical } \\
\text { orientation }\end{array}$ & Head-up or head-down posture & \\
\hline Loss of buoyancy control & $\begin{array}{l}\text { Floating at the surface or sinking to the } \\
\text { bottom }\end{array}$ & $\begin{array}{l}\text { Torpid, apathy, lethargy, weak, } \\
\text { immobility, inactivity, ceased } \\
\text { swimming, quiescent }\end{array}$ \\
\hline ABNORMAL SWIMMING BEHAVIOUR (sub-categories below) & Erratic swimming, skittering
\end{tabular}




\begin{tabular}{|c|c|c|}
\hline Corkscrew swimming & $\begin{array}{l}\text { Rotation around a long axis; erratic } \\
\text { movements, often in } \\
\text { Bursts }\end{array}$ & $\begin{array}{l}\text { Rolling, spiraling, spiral } \\
\text { swimming, tumbling, circling } \\
\text { movements }\end{array}$ \\
\hline Convulsions & $\begin{array}{l}\text { Abnormal involuntary and uncontrolled } \\
\text { contraction of muscles }\end{array}$ & $\begin{array}{l}\text { Seizures, twitching, muscle } \\
\text { spasms, shaking, shuddering, } \\
\text { vibration }\end{array}$ \\
\hline Tetany & $\begin{array}{l}\text { Rigid body musculature (intermittent or } \\
\text { permanent) }\end{array}$ & Paralysis \\
\hline Irritated skin behaviors & & Flashing, scraping, rubbing \\
\hline $\begin{array}{l}\text { Abnormal surface } \\
\text { distribution/behavior }\end{array}$ & $\begin{array}{l}\text { Abnormal depth selection, close to } \\
\text { water/air interface }\end{array}$ & $\begin{array}{l}\text { Jumping, surfacing; } \\
\text { on/at/near/just below surface/top }\end{array}$ \\
\hline $\begin{array}{l}\text { Abnormal bottom } \\
\text { distribution/behavior }\end{array}$ & $\begin{array}{l}\text { Abnormal depth selection, close to the } \\
\text { base of the tank }\end{array}$ & $\begin{array}{l}\text { Diving, sounding; lying on/ } \\
\text { orientation to / collecting at / near } \\
\text { / just above bottom }\end{array}$ \\
\hline Over-reactive to stimulus & \multirow{2}{*}{$\begin{array}{l}\text { Flight (startle) or avoidance response to: } \\
\text { visual (hand } \\
\text { passing over the top of the tank, light } \\
\text { beam), tactile (touch) or } \\
\text { vibration (tank rapped lightly) stimulus }\end{array}$} & $\begin{array}{l}\text { Hyperexcitability; hyperactivity } \\
\text { after stimulus/threat }\end{array}$ \\
\hline Under-reactive to stimulus & & $\begin{array}{l}\text { Not responsive to external } \\
\text { stimulation; inactivity after } \\
\text { stimulus/ threat }\end{array}$ \\
\hline $\begin{array}{l}\text { Loss of schooling / } \\
\text { shoaling behavior }\end{array}$ & $\begin{array}{l}\text { Individual fish show loss of aggregating } \\
\text { and social interactions }\end{array}$ & Isolation, social isolation \\
\hline $\begin{array}{l}\text { Dense schooling / } \\
\text { shoaling behavior }\end{array}$ & Increase in the clumped association of fish & Crowding \\
\hline \multicolumn{3}{|c|}{ ABNORMAL VENTILATORY (RESPIRATORY) FUNCTION (sub-categories below) } \\
\hline Hyperventilation & $\begin{array}{l}\text { Increased frequency of opercular ventilator } \\
\text { movements, with possible open mouth and } \\
\text { extended operculate }\end{array}$ & $\begin{array}{l}\text { Rapid/strong respiratory rate/ } \\
\text { function. Heavy gill movements, } \\
\text { strong ventilation, strongly } \\
\text { extended gills, abnormal } \\
\text { opercular activity, operculate } \\
\text { spread apart, mouth open }\end{array}$ \\
\hline Hypoventilation & $\begin{array}{l}\text { Decreased frequency of (and possibly } \\
\text { shallow) opercular } \\
\text { Ventilator movements }\end{array}$ & $\begin{array}{l}\text { Reduced/laboured/weak/slow } \\
\text { respiration/respiratory } \\
\text { action/ventilation }\end{array}$ \\
\hline Irregular ventilation & Irregular opercular ventilator movements & $\begin{array}{l}\text { Sporadic / spasmodic respiration / } \\
\text { gill movement }\end{array}$ \\
\hline Coughing & $\begin{array}{l}\text { Fast reflex expansion of mouth and } \\
\text { operculate not at water surface assumed to } \\
\text { clear ventilatory channels }\end{array}$ & $\begin{array}{l}\text { Gasping, abnormal opercular } \\
\text { activity, yawn }\end{array}$ \\
\hline Gulping & $\begin{array}{l}\text { Mouth (and opercular) movements at the } \\
\text { water surface, resulting in the intake of } \\
\text { water and air }\end{array}$ & Piping \\
\hline Head shaking & Rapid lateral head movements & \\
\hline \multicolumn{3}{|c|}{ ABNORMAL SKIN PIGMENTATION (sub-categories below) } \\
\hline Darkened & & $\begin{array}{l}\text { Changed / increased / dark(ened) } \\
\text { color / pigmentation / melanistic } \\
\text { markings }\end{array}$ \\
\hline Lightened & & $\begin{array}{l}\text { Pallor, pale/changed/weak } \\
\text { pigmentation }\end{array}$ \\
\hline Mottled & & Discolored patches \\
\hline \multicolumn{3}{|c|}{ OTHER VISIBLE (APPEARANCE \& BEHAVIOUR) ABNORMALITIES (sub-categories below) } \\
\hline Exophthalmia & $\begin{array}{l}\text { Swelling within the orbital socket(s) } \\
\text { resulting in bulging of one or both eyes }\end{array}$ & $\begin{array}{l}\text { Exophthalmos, exophthalmos, } \\
\text { popeye, protruding eyeball }\end{array}$ \\
\hline Edema & $\begin{array}{l}\text { Abdominal swelling due to the } \\
\text { accumulation of fluid. May cause } \\
\text { protruding scales and/or fissure in the } \\
\text { abdominal wall }\end{array}$ & $\begin{array}{l}\text { Distended/swollen/bloated } \\
\text { abdomen/gut area; dropsy }\end{array}$ \\
\hline Hemorrhage & $\begin{array}{l}\text { Petechiae (pinhead-sized spots) and/or } \\
\text { hematoma (area of } \\
\text { blood) due to intradermal or sub-mucus } \\
\text { bleeding }\end{array}$ & \\
\hline
\end{tabular}


Mucus secretion

\section{(n)}

Fecal (anal) casts

Aggression and/or

cannibalism
Mucus build-up (close pay attention to eyes); increased secretion (mucus on the skin or in water); mucus loss

String of feces hanging from the anus or on the tank floor

Table 3. Finney's table for the transformation of percentages of mortality to probit values (Finney, 1952).

\begin{tabular}{l|l|l|l|l|l|l|l|l|l|l}
$\mathbf{\%}$ & $\mathbf{0}$ & $\mathbf{1}$ & $\mathbf{2}$ & $\mathbf{3}$ & $\mathbf{4}$ & $\mathbf{5}$ & $\mathbf{6}$ & $\mathbf{7}$ & $\mathbf{8}$ & $\mathbf{9}$ \\
\hline $\mathbf{0}$ & - & 2.67 & 2.95 & 3.12 & 3.25 & 3.36 & 3.45 & 3.52 & 3.59 & 3.66 \\
\hline $\mathbf{1 0}$ & 3.72 & 3.77 & 3.82 & 3.87 & 3.92 & 3.96 & 4.01 & 4.05 & 4.08 & 4.12 \\
\hline $\mathbf{2 0}$ & 4.16 & 4.19 & 4.23 & 4.26 & 4.29 & 4.33 & 4.36 & 4.39 & 4.42 & 4.45 \\
\hline $\mathbf{3 0}$ & 4.48 & 4.50 & 4.53 & 4.56 & 4.59 & 4.61 & 4.64 & 4.67 & 4.69 & 4.72 \\
\hline $\mathbf{4 0}$ & 4.75 & 4.77 & 4.80 & 4.82 & 4.85 & 4.87 & 4.90 & 4.92 & 4.95 & 4.97 \\
\hline $\mathbf{5 0}$ & 5.00 & 5.03 & 5.05 & 5.08 & 5.10 & 5.13 & 5.15 & 5.18 & 5.20 & 5.23 \\
\hline $\mathbf{6 0}$ & 5.25 & 5.28 & 5.31 & 5.33 & 5.36 & 5.39 & 5.41 & 5.44 & 5.47 & 5.50 \\
\hline $\mathbf{7 0}$ & 5.52 & 5.55 & 5.58 & 5.61 & 5.64 & 5.67 & 5.71 & 5.74 & 5.77 & 5.81 \\
\hline $\mathbf{8 0}$ & 5.84 & 5.88 & 5.92 & 5.95 & 5.99 & 6.04 & 6.08 & 6.13 & 6.18 & 6.23 \\
\hline $\mathbf{9 0}$ & 6.28 & 6.34 & 6.41 & 6.48 & 6.55 & 6.64 & 6.75 & 6.88 & 7.05 & 7.33 \\
\hline- & 0.0 & 0.1 & 0.2 & 0.3 & 0.4 & 0.5 & 0.6 & 0.7 & 0.8 & 0.9 \\
\hline $\mathbf{9 9}$ & 7.33 & 7.37 & 7.41 & 7.46 & 7.51 & 7.58 & 7.65 & 7.75 & 7.88 & 8.09 \\
\hline $\mathbf{9}$ & $\mathbf{0}$ & $\mathbf{1}$ & $\mathbf{2}$ & $\mathbf{3}$ & $\mathbf{4}$ & $\mathbf{5}$ & $\mathbf{6}$ & $\mathbf{7}$ & $\mathbf{8}$ & $\mathbf{9}$ \\
\hline $\mathbf{0}$ & - & 2.67 & 2.95 & 3.12 & 3.25 & 3.36 & 3.45 & 3.52 & 3.59 & 3.66 \\
\hline $\mathbf{1 0}$ & 3.72 & 3.77 & 3.82 & 3.87 & 3.92 & 3.96 & 4.01 & 4.05 & 4.08 & 4.12 \\
\hline $\mathbf{2 0}$ & 4.16 & 4.19 & 4.23 & 4.26 & 4.29 & 4.33 & 4.36 & 4.39 & 4.42 & 4.45 \\
\hline $\mathbf{3 0}$ & 4.48 & 4.50 & 4.53 & 4.56 & 4.59 & 4.61 & 4.64 & 4.67 & 4.69 & 4.72 \\
\hline $\mathbf{4 0}$ & 4.75 & 4.77 & 4.80 & 4.82 & 4.85 & 4.87 & 4.90 & 4.92 & 4.95 & 4.97 \\
\hline $\mathbf{5 0}$ & 5.00 & 5.03 & 5.05 & 5.08 & 5.10 & 5.13 & 5.15 & 5.18 & 5.20 & 5.23 \\
\hline $\mathbf{6 0}$ & 5.25 & 5.28 & 5.31 & 5.33 & 5.36 & 5.39 & 5.41 & 5.44 & 5.47 & 5.50 \\
\hline $\mathbf{7 0}$ & 5.52 & 5.55 & 5.58 & 5.61 & 5.64 & 5.67 & 5.71 & 5.74 & 5.77 & 5.81 \\
\hline $\mathbf{8 0}$ & 5.84 & 5.88 & 5.92 & 5.95 & 5.99 & 6.04 & 6.08 & 6.13 & 6.18 & 6.23 \\
\hline $\mathbf{9 0}$ & 6.28 & 6.34 & 6.41 & 6.48 & 6.55 & 6.64 & 6.75 & 6.88 & 7.05 & 7.33 \\
\hline- & 0.0 & 0.1 & 0.2 & 0.3 & 0.4 & 0.5 & 0.6 & 0.7 & 0.8 & 0.9 \\
\hline $\mathbf{9 9}$ & 7.33 & 7.37 & 7.41 & 7.46 & 7.51 & 7.58 & 7.65 & 7.75 & 7.88 & 8.09
\end{tabular}

Table 4. Mortality table for Kandhamal haladi with probit value.

\begin{tabular}{l|c|c|c|c|c} 
Conc. $(\boldsymbol{\mu M})$ & $\mathbf{l o g} \mathbf{1 0}$ (conc.) & $\begin{array}{c}\text { Zebrafish } \\
(\mathbf{N = 2 1})\end{array}$ & $\begin{array}{c}\text { No of death after } \\
\mathbf{9 6} \mathbf{~ h r}\end{array}$ & $\begin{array}{c}\text { Zebrafish death } \\
(\mathbf{\%})\end{array}$ & $\begin{array}{c}\text { Probit } \\
\text { value }\end{array}$ \\
\hline Naive & - & 21 & 0 & 0 & - \\
\hline Control & - & 21 & 0 & 0 & - \\
\hline $\mathbf{2 0}$ & 1.30103 & 21 & 0 & 0 & 0 \\
\hline $\mathbf{4 0}$ & 1.60206 & 21 & 2 & 10 & 3.72 \\
\hline $\mathbf{6 0}$ & 1.778151 & 21 & 3 & 14 & 3.92 \\
\hline $\mathbf{8 0}$ & 1.90309 & 21 & 3 & 14 & 3.92 \\
\hline $\mathbf{1 0 0}$ & 2 & 21 & 5 & 24 & 4.29 \\
\hline $\mathbf{1 2 0}$ & 2.079181 & 21 & 6 & 29 & 4.45 \\
\hline $\mathbf{1 4 0}$ & 2.146128 & 21 & 8 & 38 & 4.69 \\
\hline $\mathbf{1 6 0}$ & 2.20412 & 21 & 9 & 43 & 4.82 \\
\hline $\mathbf{1 8 0}$ & 2.255273 & 21 & 9 & 43 & 4.82 \\
\hline $\mathbf{2 0 0}$ & 2.30103 & 21 & 12 & 57 & 5.18 \\
\hline $\mathbf{2 2 0}$ & 2.342423 & 21 & 12 & 57 & 5.18 \\
\hline $\mathbf{2 4 0}$ & 2.380211 & 21 & 14 & 67 & 5.44 \\
\hline $\mathbf{2 6 0}$ & 2.414973 & 21 & 15 & 71 & 5.55 \\
\hline $\mathbf{2 8 0}$ & 2.447158 & 21 & 15 & 71 & 5.55 \\
\hline $\mathbf{3 0 0}$ & 2.477121 & 21 & 18 & 86 & 6.08
\end{tabular}

Table 5. $\mathrm{LC}_{1-99}$ values and associated $95 \%$ confidence limit for the zebrafish that experienced mortality when exposed to Kandhamal haladi.

95\% Confidence Limits for Concentration $(\mu \mathrm{M})$

\begin{tabular}{l|l|l|l}
\hline Lethal concentration & Estimate & Lower Bound & Upper Bound \\
\hline LC $_{\mathbf{1}}$ & 24.313 & 12.760 & 36.060 \\
\hline LC $_{\mathbf{1 0}}$ & 58.771 & 40.786 & 74.132
\end{tabular}




\begin{tabular}{l|l|l|l}
$\mathbf{L} \mathbf{L C}_{\mathbf{2 0}}$ & 85.224 & 65.911 & 101.355 \\
\hline $\mathbf{L C}_{\mathbf{3 0}}$ & 111.416 & 92.157 & 128.390 \\
\hline $\mathbf{L C}_{\mathbf{4 0}}$ & 140.085 & 120.770 & 159.670 \\
\hline $\mathbf{L} \mathbf{C}_{\mathbf{5 0}}$ & 173.516 & 152.146 & 200.072 \\
\hline $\mathbf{L C}_{\mathbf{6 0}}$ & 214.925 & 187.445 & 256.355 \\
\hline $\mathbf{L C}_{\mathbf{7 0}}$ & 270.229 & 230.363 & 339.959 \\
\hline $\mathbf{L C}_{\mathbf{8 0}}$ & 353.277 & 289.790 & 478.641 \\
\hline $\mathbf{L} \mathbf{C}_{90}$ & 512.292 & 394.605 & 776.634 \\
\hline $\mathbf{L} \mathbf{C}_{\mathbf{9 5}}$ & 696.316 & 507.231 & 1162.760 \\
\hline $\mathbf{L} \mathbf{C}_{99}$ & 1238.325 & 808.966 & 2489.412
\end{tabular}

Table 6. Parameter estimates of $96 \mathrm{~h} \mathrm{LC}_{50}$ probit analysis for Kandhamal haladi.

a. PROBIT model: PROBIT $(\mathrm{p})=$ Intercept $+\mathrm{BX}($ Covariates $\mathrm{X}$ are transformed using the base 10.000 logarithm).

\begin{tabular}{|c|c|c|c|c|c|c|c|}
\hline \multicolumn{2}{|c|}{ Parameter } & \multirow[t]{2}{*}{ Estimate } & \multirow[t]{2}{*}{$\begin{array}{l}\text { Std. } \\
\text { Error }\end{array}$} & \multirow[t]{2}{*}{ Z } & \multirow[t]{2}{*}{ Sig. } & \multicolumn{2}{|c|}{$\begin{array}{l}\text { 95\% Confidence } \\
\text { Interval }\end{array}$} \\
\hline & & & & & & $\begin{array}{l}\text { Lower } \\
\text { Bound }\end{array}$ & $\begin{array}{l}\text { Upper } \\
\text { Bound }\end{array}$ \\
\hline \multirow[t]{2}{*}{ PROBIT $^{\mathrm{a}}$} & Concentration $(\mu \mathrm{M})$ & 2.726 & 0.347 & 7.847 & 0.000 & 2.045 & 3.406 \\
\hline & Intercept & -6.104 & 0.769 & -7.932 & 0.000 & -6.873 & -5.334 \\
\hline
\end{tabular}

Table 7. Chi-square tests of $96 \mathrm{~h} \mathrm{LC}_{50}$ probit analysis for Kandhamal haladi.

\begin{tabular}{l|l|l|l|l}
\multicolumn{2}{l|}{} & Chi-Square & $\mathrm{df}^{\mathrm{b}}$ & Sig. \\
\hline PROBIT & $\begin{array}{l}\text { Pearson } \\
\text { Goodness-of- } \\
\text { Fit Test }\end{array}$ & 4.931 & 13 & $.977^{\mathrm{a}}$ \\
\hline
\end{tabular}

a. Since the significance level is greater than .150 , no heterogeneity factor is used in the calculation of confidence limits.

b. Statistics based on individual cases differ from statistics based on aggregated cases.

Table 8. $96 \mathrm{~h} \mathrm{LC}_{50}$ values for freshwater zebrafish after exposure to Kandhamal haladi by using two methods.

\begin{tabular}{l|l|l} 
Methods & 96h LC50 value $(\mu \mathrm{M})$ & Regression equation \\
\hline Finney's probit analysis using MS Office & 173.780 & $\begin{array}{l}\mathrm{y}=0.290 \mathrm{x}-4.828 \\
\mathrm{R}^{2}=0.986\end{array}$ \\
$\begin{array}{l}\text { Excel 2007 } \\
\begin{array}{l}\text { Finney's probit analysis using IBM SPSS } \\
\text { statistics 25 }\end{array}\end{array}$ & $\begin{array}{l}\mathrm{y}=-5.77+2.58^{*} \mathrm{x} \\
\mathrm{R}^{2} \text { linear }=0.926\end{array}$
\end{tabular}

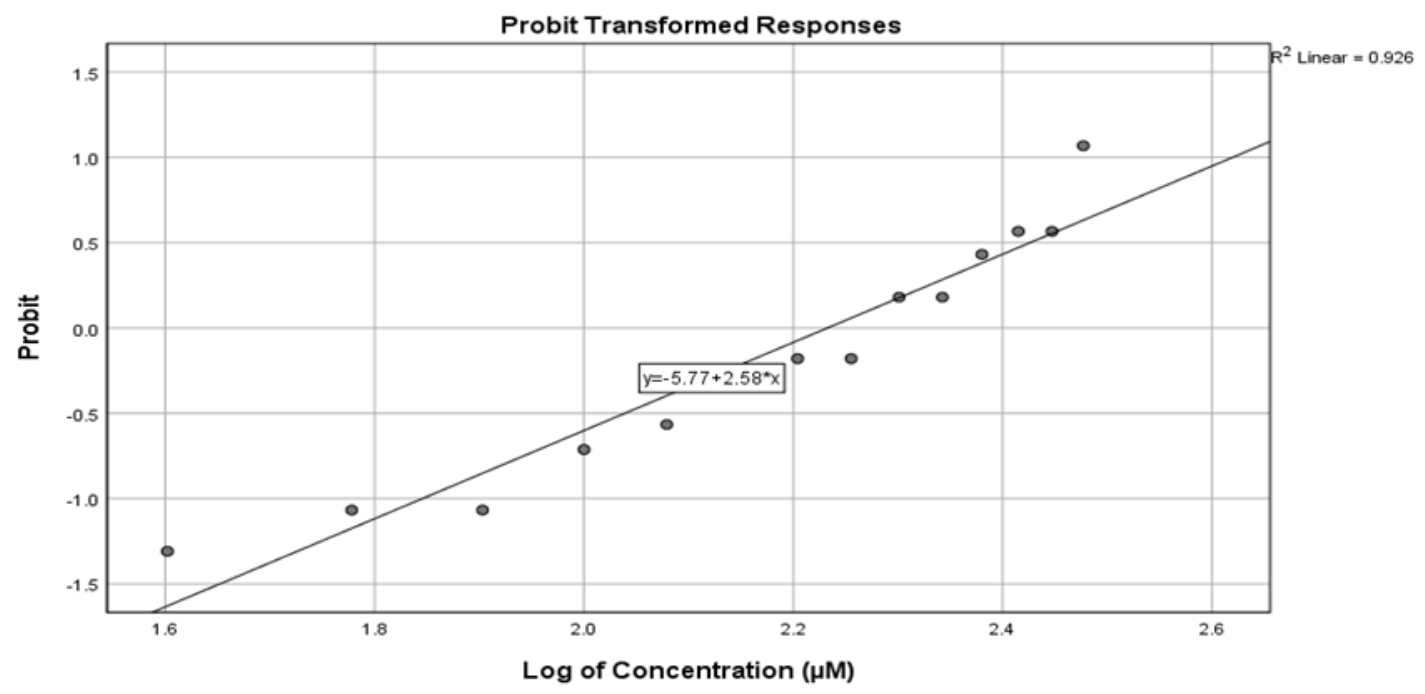

Figure 5. The graph showing linear curve between probit mortality of fish against log concentration in Danio rerio on exposure to Kandhamal haladi using IBM SPSS Statistics 25. 


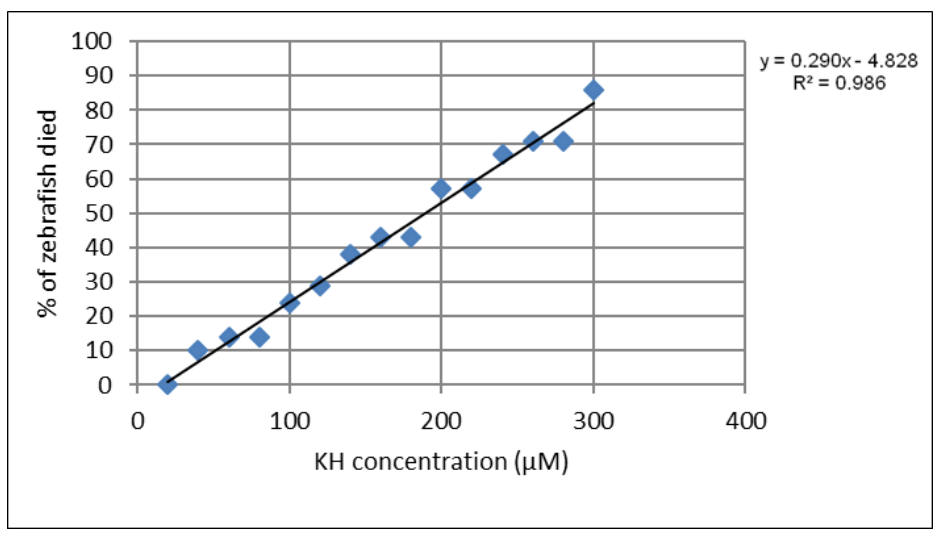

Figure 6. The graph showing the linear curve between the mortality percentage of fish against log concentration in Danio rerio on exposure to Kandhamal haladi using MS Office Excel-2007.

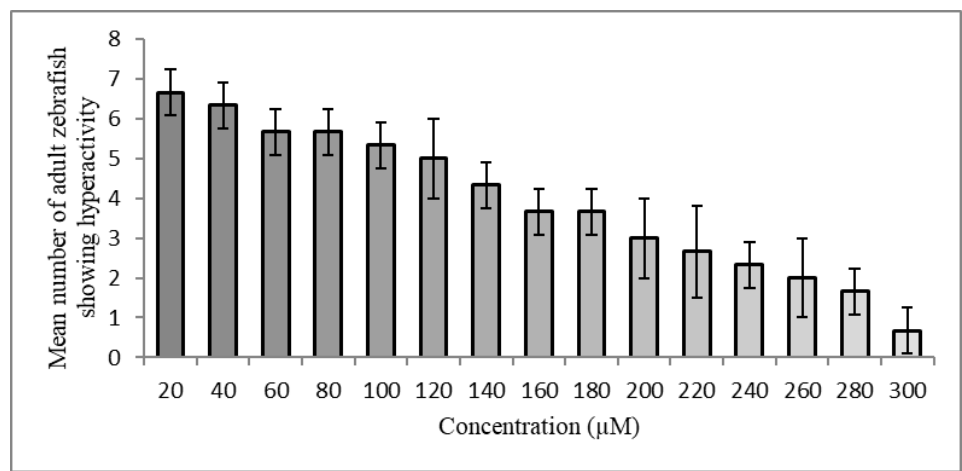

Figure 7. Number of adult zebrafish showing hypersensitivity exposed to Kandhamal haladi for 96hrs. Values are represented as Mean $\pm \operatorname{SEM}(n=7)$.

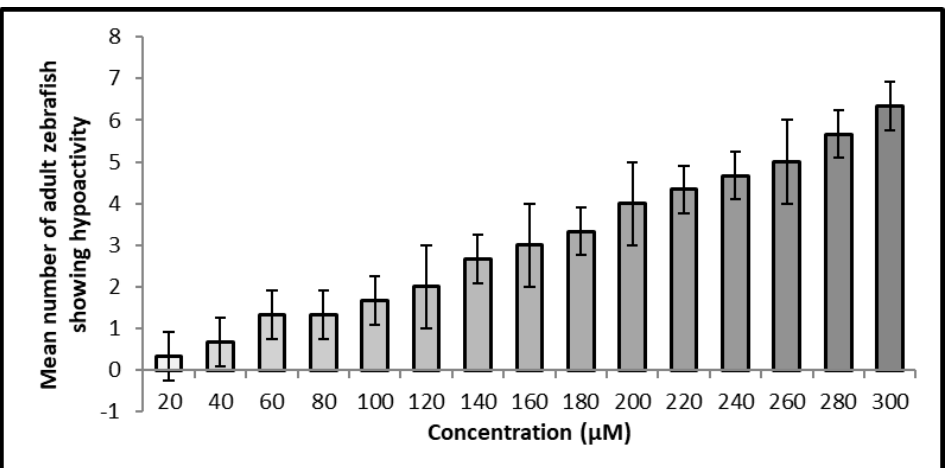

Figure 8. Number of adult zebrafish showing hyposensitivity exposed to Kandhamal haladi for 96hrs. Values are represented as Mean $\pm \operatorname{SEM}(n=7)$.

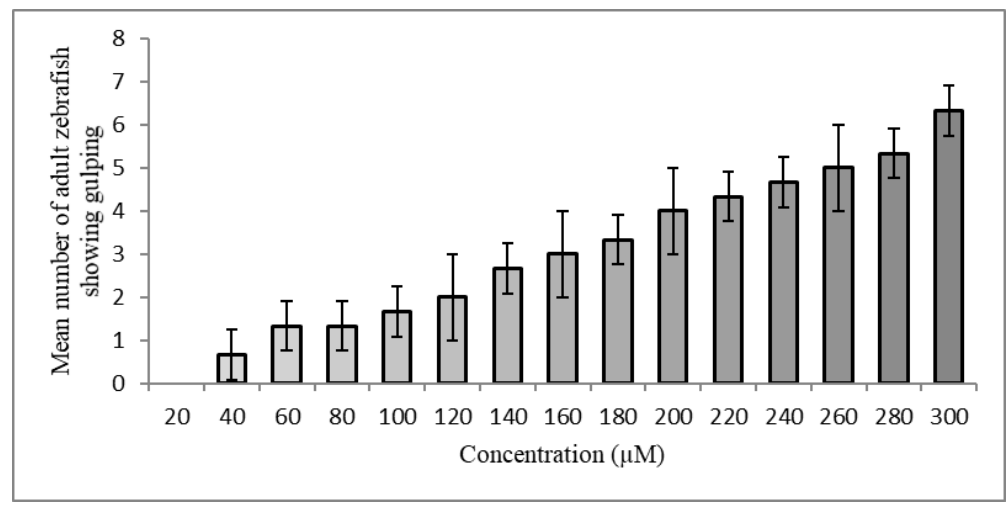

Figure 9. Number of adult zebrafish showing gulping behavior exposed to Kandhamal haladi for 96hrs. Values are represented as Mean $\pm \operatorname{SEM}(n=7)$. 


\section{Conclusions}

From the results of this experiment, it was found that there was a positive relationship between the mortality and concentration levels; when the concentration level increased, the mortality rate also increased. However, there was a negative relationship between the mortality time and concentration level; when the concentration level increased, the mortality time decreased. Also, behavioral changes increased with increased concentration of Kandhamal haladi. We applied two statistical methods of data evaluation for acute toxicity assessment. Our results were similar in the two methods used. Our findings suggest that Kandhamal haladi can be used to fight against different fish diseases because of its low toxic effect on fishes, and supplementation of haladi could be recommended in aquaculture through the feed to prevent disease impact.

\section{Funding}

This research received no external funding.

\section{Acknowledgments}

This research has no acknowledgment.

\section{Conflicts of Interest}

The authors declare no conflict of interest.

\section{References}

1. Hansen, C.; Maule, A.F. Pehr Osbeck's collections and Linnaeus's Species plantarum (1753). Botanical Journal of the Linnean Society 1973, 67, 189-212, https://doi.org/10.1111/j.1095-8339.1973.tb01738.x.

2. Nair, K.P. Turmeric (Curcuma Longa L.) and Ginger (Zingiber Officinale Rosc.)-World's Invaluable Medicinal Spices: The Agronomy and Economy of Turmeric and Ginger. 1st ed.; Springer International Publishing: Switzerland AG, 2019; pp. 1-66, https://doi.org/10.1007/978-3-030-29189-1

3. Abdeldaiem M.H. Use of Yellow Pigment Extracted from Turmeric (Curcuma Longa) Rhizomes Powder as Natural Food Preservative. American Journal of Food Science and Technology 2014, 2, 36-47.

4. Biodiversity library Hortus indicus malabaricus. https://doi.org/10.5962/bhl.title.707.

5. Middleton, D.J. Brian Laurence Burtt. Edinburgh Journal of Botany 2009, 66, 1-26, https://doi.org/10.1017/S0960428609005459.

6. Biodiversity library Flora of British India, Volume II. https://doi.org/10.5962/bhl.title.678.

7. Chattopadhyay, I.; Biswas, K.; Bandyopadhyay, U.; Banerjee, R.K. Turmeric and curcumin: Biological actions and medicinal applications. Current science 2004, 87, 44-53.

8. Priyadarsini, K.I. The chemistry of curcumin: from extraction to therapeutic agent. Molecules 2014, 19, 20091-20112, https://doi.org/10.3390/molecules191220091.

9. Rajkumari, S.; Sanatombi, K. Nutritional value, phytochemical composition, and biological activities of edible Curcuma species: A review. International journal of food properties 2017, 20, 2668-2687, https://doi.org/10.1080/10942912.2017.1387556

10. Mishra, S.; Palanivelu, K. The effect of curcumin (turmeric) on Alzheimer's disease: An overview. Annals of Indian Academy of Neurology 2008, 11, https://doi.org/10.4103/0972-2327.40220.

11. Selvi, N.M.K.; Sridhar, M.G.; Swaminathan, R.P.; Sripradha, R. Efficacy of turmeric as adjuvant therapy in type 2 diabetic patients. Indian Journal of Clinical Biochemistry 2015, 30, 180-186, https://doi.org/10.1007/s12291-014-0436-2.

12. Watson, R.R. Foods and dietary supplements in the prevention and treatment of disease in older adults. 1st Ed.; Academic Press: San Diego, U.S.A., 2015; pp. 111-116. https://doi.org/10.1016/C2013-0-00305-2.

13. Liu, Y.M.; Zhang, Q.Z.; Xu, D.H.; Fu, Y.W.; Lin, D.J.; Zhou, S.Y.; Li, J.P. Antiparasitic efficacy of curcumin from Curcuma longa against Ichthyophthirius multifiliis in grass carp. Veterinary parasitology 2017, 236, 128-136, https://doi.org/10.1016/j.vetpar.2017.02.011. 
14. Kaur, A.; Holeyappa, S.A.; Bansal, N.; Kaur, V.I.; Tyagi, A. Ameliorative effect of turmeric supplementation in feed of Labeo rohita (Linn.) challenged with pathogenic Aeromonas veronii. Aquaculture International 2020, 28, 1169-1182, https://doi.org/10.1007/s10499-020-00518-z.

15. Kent, M.L.; Whipps, C.M.; Matthews, J.L.; Florio, D.; Watral, V.; Bishop-Stewart, J.K.; Poort, M.; Bermudez, L. Mycobacteriosis in zebrafish (Danio rerio) research facilities. Comparative Biochemistry and Physiology Part C: Toxicology \& Pharmacology 2004, 138, 383-390, https://doi.org/10.1016/j.cca.2004.08.005.

16. Matthews, J. L. Common diseases of laboratory zebrafish. In: Methods in cell biology. 1st ed.; Detrich III, H.W., Zon, L., Westerfield, M., Eds.; Academic Press: San Diego, U.S.A., Volume 77, 2009; pp. 617-643, https://doi.org/10.1016/S0091-679X(04)77033-8.

17. Esmail, M.Y.; Astrofsky, K.M.; Lawrence, C.; Serluca, F.C. The Biology and Management of the Zebrafish. In: Laboratory Animal Medicine. 3rd ed.; Fox, J.G.; Otto, G.M.; Whary, M.T.; Anderson, L.C.; PritchettCorning, K.R. Eds.; Academic Press: San Diego, U.S.A., 2015; pp. 1015-1062, https://doi.org/10.1016/B978-0-12-409527-4.00020-1.

18. Gauthier, D.T.; Rhodes, M.W. Mycobacteriosis in fishes: a review. The Veterinary Journal 2009, 180, 3347, https://doi.org/10.1016/j.tvj1.2008.05.012.

19. Tell, L.A.; Woods, L.; Cromie, R.L. Mycobacteriosis in birds. Revue Scientifique et Technique-Office International des Epizooties 2001, 20, 180-203, https://doi.org/10.20506/rst.20.1.1273.

20. Dosoky, N.S.; Setzer, W.N. Chemical Composition and Biological Activities of Essential Oils of Curcuma Species. Nutrients 2018, 10, https://doi.org/10.3390/nu10091196.

21. Rajagopal, R.E.; Balasubramanian, M.; Kalyanaraman, S. Raw turmeric and pure curcumin: a comparison of embryonic cytotoxicity in zebrafish. IJBCP International Journal of Basic \& Clinical Pharmacology 2017, 6, 2020-2026, http://dx.doi.org/10.18203/2319-2003.ijbcp20173290

22. Amalraj, A.; Pius, A.; Gopi, S.; Gopi, S. Biological activities of curcuminoids, other biomolecules from turmeric and their derivatives-A review. Journal of traditional and complementary medicine 2017, 7, 205233, https://doi.org/10.1016/j.jtcme.2016.05.005.

23. Das, K. Prospects and challenges of geographical indications in India. The Journal of World Intellectual Property 2010, 13, 148-201, https://doi.org/10.1111/j.1747-1796.2009.00363.x.

24. Kandhamal Apex Spices Association for Marketing (KASAM). Available online: http://www.indianspicesociety.in/iss/pdf/KASAM\%20-\%20Product\%20Profile\%20Broucher.pdf accessed on 26 May 2020.

25. Biodiversity library An account of the fishes found in the river Ganges and its branches. (26 May 2020). https://doi.org/10.5962/bhl.title.6897.

26. Freeman, A.; Holland, R.; Hwang-Shum, J.J.; Lains, D.; Matthews, J.; Murray, K.; Nasiadka, A.; Quinn, E.; Varga, Z.M.; Westerfield, M. The Zebrafish International Resource Center. The Biological Resources of Model Organisms: Collection, Characterization and Applications. 1st ed.; Jarret, R. L., McCluskey, K. Eds.; CRC Press: Boca Raton, Unites States, 2019; pp. 108-139, https://doi.org/10.1201/9781315100999.

27. Common Names List- Danio rerio- Fish Base. Available online: https://www.fishbase.se/ComNames/CommonNamesList.php?id=4653\&genusname=Danio\&speciesname $=$ rerio\&stockcode $=4841 \&$ lang=english (26 May 2020).

28. Parichy, D.M.; Postlethwait, J.H. The biotic and abiotic environment of zebrafish. Behavioral and Neural Genetics of Zebrafish. Gerlai, R.T. Eds.; Academic Press: San Diego, U.S.A., 2020; pp. 3-16, https://doi.org/10.1016/B978-0-12-817528-6.00001-2.

29. Spence, R.; Gerlach, G.; Lawrence, C.; Smith, C. The behaviour and ecology of the zebrafish, Danio rerio. Biological reviews 2008, 83, 13-34, https://doi.org/10.1111/j.1469-185X.2007.00030.x.

30. Varga, M. The Doctor of Delayed Publications: The Remarkable Life of George Streisinger (1927-1984). Zebrafish 2018, 15, 314-319, https://doi.org/10.1089/zeb.2017.1531.

31. Kimmel, C.B.; Ballard, W.W.; Kimmel, S.R.; Ullmann, B.; Schilling, T.F. Stages of embryonic development of the zebrafish. Developmental dynamics 1995, 203, 253-310, https://doi.org/10.1002/aja.1002030302.

32. Spitsbergen, J.M.; Kent, M.L. The state of the art of the zebrafish model for toxicology and toxicologic pathology research-advantages and current limitations. Toxicologic pathology 2003, 31(1_suppl), 62-87, https://doi.org/10.1080/01926230390174959.

33. Fleming, A.; Rubinsztein, D.C. Zebrafish as a model to understand autophagy and its role in neurological disease. Biochimica et Biophysica Acta (BBA)-Molecular Basis of Disease 2011, 1812, 520-526, https://doi.org/10.1016/j.bbadis.2011.01.004.

34. Zhu, J.J.; Xu, Y.Q.; He, J.H.; Yu, H.P.; Huang, C.J.; Gao, J.M.; Dong, Q.X.; Xuan, Y.X.; Li, C.Q. Human cardiotoxic drugs delivered by soaking and microinjection induce cardiovascular toxicity in zebrafish. Journal of Applied Toxicology 2014, 34, 139-148, https://doi.org/10.1002/jat.2843.

35. Gao, X.P.; Feng, F.; Zhang, X.Q.; Liu, X.X.; Wang, Y.B.; She, J.X.; He, M.F. Toxicity assessment of 7 anticancer compounds in zebrafish. International journal of toxicology 2014, 33, 98-105, https://doi.org/10.1177/1091581814523142.

36. McGrath, P.; Li, C.Q. Zebrafish: a predictive model for assessing drug-induced toxicity. Drug discovery today 2008, 13, 394-401, https://doi.org/10.1016/j.drudis.2008.03.002. 
37. Howe, K.; Clark, M.D.; Torroja, C.F.; Torrance, J.; Berthelot, C.; Muffato, M.; McLaren, S. The zebrafish reference genome sequence and its relationship to the human genome. Nature 2013, 496, 498-503, https://doi.org/10.1038/nature12111.

38. Rose, R.L.; Hodgson E. Metabolism of Toxicants. A textbook of modern toxicology. 3rd ed.; Hodgson, E. Eds.; John Wiley \& Sons: New Jersey, United States, 2004; pp. 111-148, https://doi.org/10.1002/0471646776.

39. Test No. 203: Fish, Acute Toxicity Test published by OECD. Available online: https://www.oecdilibrary.org/environment/test-no-203-fish-acute-toxicity test_9789264069961-en (accessed 18 June 2019). https://doi.org/10.1787/9789264069961-en.

40. Scholz, S.; Ortmann, J.; Klüver, N.; Léonard, M. Extensive review of fish embryo acute toxicities for the prediction of GHS acute systemic toxicity categories. Regulatory toxicology and pharmacology: RTP 2014, 69, 572-579, https://doi.org/10.1016/j.yrtph.2014.06.004.

41. Lawrence, C.; Mason, T. Zebrafish housing systems: a review of basic operating principles and considerations for design and functionality. ILAR journal 2012, 53, 179-191, https://doi.org/10.1093/ilar.53.2.179.

42. Avdesh, A.; Chen, M.; Martin-Iverson, M.T.; Mondal, A.; Ong, D.; Rainey-Smith, S.; Taddei, K.; Lardelli, M.; Groth, D.M.; Verdile, G.; Martins, R.N. Regular Care and Maintenance of a Zebrafish (Danio rerio) Laboratory: An Introduction. J. Vis. Exp. 2012, 69, https://doi.org/10.3791/4196.

43. Singleman, C.; Holtzman, N.G. Growth and maturation in the zebrafish, Danio rerio: a staging tool for teaching and research. Zebrafish 2014, 11, 396-406, https://doi.org/10.1089/zeb.2014.0976.

44. Huang, Y.; Cartlidge, R.; Walpitagama, M.; Kaslin, J.; Campana, O.; Wlodkowic, D. Unsuitable use of DMSO for assessing behavioral endpoints in aquatic model species. The science of the total environment 2018, 615, 107-114, https://doi.org/10.1016/j.scitotenv.2017.09.260.

45. Finney, D.J. Statistical logic in the monitoring of reactions to therapeutic drugs. Methods of information in medicine 1971, 10, 237-245, https://doi.org/10.1055/s-0038-1636052.

46. Shah, S.L.; Altindağ, A. Effects of Heavy Metal Accumulation on the 96-h LC_50 Values in Tench Tinca tinca L., 1758. Turkish Journal of Veterinary and Animal Sciences 2005, 29, 139-144. 